\title{
The Dissemination of Military Perspective through Fortification Treatises between the Sixteenth and Eighteenth Centuries
}

\author{
Jorge Galindo Díaz
}

Published online: 20 September 2014

(C) Kim Williams Books, Turin 2014

\begin{abstract}
This paper describes the rapid dissemination of the technique of military perspective by writers of fortification treatises beginning in the sixteenth century in France and Spain, thanks to the operational advantages it represented for engineers of the time. The study reviews the analyses of authors who dedicated chapters to the topic and surveys the images that shaped their impressions.
\end{abstract}

Keywords Military architecture - Fortifications - Historical treatises · Perspective $\cdot$ Military perspective $\cdot$ Descriptive geometry $\cdot$ Jean Du Breuil · Ambroise Bachot · Alonso de Cepeda y Adrada - Vicente Tosca $\cdot$ Blaise François Pagan

\section{Introduction}

Although many studies have examined the origin, dissemination, and application of conic perspective in artistic and scientific fields during the period between the 16th and 18th centuries, very few have considered what is called "parallel" or "axonometric perspective" (the category within which military, cavalier, and isometric perspectives are usually considered). In many cases, axonometric perspective has been classified as a simplification of conic perspective, and is therefore considered to be of lesser value and complexity (D'Orgeix 2008).

However, axonometries were used intuitively beginning in the 12th century. Based on the concept of visual parallel rays, this was considered a form of artificial perspective supported by a purely Euclidian method of construction (Deforge 1981); this condition gave the impression to scholars and practitioners the axonometric

\section{J. Galindo Díaz $(\bowtie)$}

School of Architecture and Urbanism, National University of Colombia,

Carrera 27 No. 64-60, Manizales, Colombia

e-mail: jagalindod@unal.edu.co 
perspective produced an anti-natural optical effect, despite its effectiveness in representing machines in a simple manner-as performed by Francesco Di Giorgio Martini, for example, in his manuscript from approximately 1480, Trattato di Architettura, or Il Taccola, author of another manuscript from 1433, called Liber tertius de ingeneis ac edifitis non usitatis-and in technical projects where dimensional aspects played an important role in the authors' descriptions, as occurred in the design of fortified buildings (Vérin 2006).

One of the first specific uses of military perspective was in the work of Maggi and Castriotto, Della fortificatione della cittá (1564), who called it prospettiva soldatesca (soldierly perspective) and used it to illustrate siege scenes and especially the constructive possibilities of sections of walls. However, for many treatise writers from the sixteenth and seventeenth centuries, the parallel perspective was nothing more than a "common perspective" or a drawing tool that was only useful for practical purposes (Camerota 2008).

This paper analyses how military perspective was disseminated through fortification treatises beginning with publications by Bachot (Bachot 1587, 1598) and then replicated by various French and Spanish authors until it was consolidated in the work of Brueil (1674) as the most appropriate method of representing the interests of the engineer to achieve optimal results in developing technical projects. To that end, we survey the contents of these works to specify both how axonometry was used and the arguments that were made to promote its use.

\section{Ambroise Bachot: The Precursor of Military Perspective}

When Ambroise Bachot published his first book in 1587, Le timon du capitain Ambroise Bachot... (Paris, A. Bachot), which advocated for the use of a tridimensional representation system that would not change the geometry of a plan to measure it, Jacques Androuet du Cerceau had already rationally justified the use of the parallel perspective 5 years before in his Livre III d'architecture (1582), which concerned the calculation of the surface area of buildings to be constructed.

In the last third of the sixteenth century, du Cerceau had become a celebrated author as a result of more than six books. Those that stand out include Leçons de perspective positive, (1576a, b), Le premier volume des plus excellents bastiments de France (1576b-1579), and Petit traitte des cinq ordres de colomnes (1583), all of which were illustrated using beautiful engravings that represented different types of buildings, courtyard designs, fountains, furniture, chimneys, and a large variety of architectonic elements, and that always employed either conic or axonometric perspectives as a means of representation. The author's proficiency in conic perspective is clear when looking at his book Leçons de perspective positive (1576a, b), where the author highlighted the practical aspect over the scientific aspect of perspective through sixty "lessons", all of which referred to specific cases of complete buildings or their parts. With regard to du Cerceau's skill in parallel perspective, we can rely on the illustrations in Plus excellents bastiments de France (1576b-1579) and again the Livre III d'architecture (1582). However, the author's 
use of parallel perspective was limited to the representation of buildings, and he did not explore its real advantages for the civil engineer or architect.

In contrast to du Cerceau, Ambroise Bachot clearly established the importance of the axonometric perspective as a method of representing fortified buildings in a brief address in the first of his printed books, Le timon du capitaine Ambroise Bachot ...:

Ami lecteur, tu dois ici avec grande considération connaître un essai admirable sur le sujet de l'architecture des fortifications lequel est tel qu'en représentant les corps élevés d'une forteresse, la perspective ne doit en rien changer la forme et dimension du plan géométrique à celle fin que l'on se puisse toujours mesurer quand il sera de besoin ce qui ne se peut faire ni observer par la règle de la perspective qui se conduit avec un point principal et deux tiers points. Cette manière dont il est question pour représenter les dessins des fortifications est fort familière et facile à entendre, l'effet d'icelle ne gît qu'en tirant les lignes perpendiculaires du plan géométrial et rapportant sur icelles perpendiculaires les hauteurs ou profondeurs au-dessus ou dessous ledit plan, lequel représente la superficie de la terre, et assembler lesdites lignes dessus et dessous avec lignes parallèles ce qu'observant diligentement tu auras l'effet de ton intention.

(Dear reader, it is quite important for you to know of an admirable essay on the topic of architecture of fortifications through which, to represent the elevations of a fortress, is used that in no way changes the form and dimension of the geometric plant, in a way that whenever necessary we can measure, which cannot be done or observed through the rules of perspective constructed with a principal point. Thus, designs are represented in easily understood and familiar manner, given that their effect is accomplished by raising perpendicular lines from the geometric plant and joining those lines above or below the plant representing the surface of the earth with parallel lines in such a way that the desired effect is achieved (Bachot 1587): 26, my trans.)

Bachot begins the discussion with a dedication and a greeting to the readers. Next, he examines pratique de géométrie (the practice of geometry), where problems were developed relative to planar figures through constructions based on the use of the compass, all of which was combined with a brief discours sur géométrie (discourse on geometry). He then introduces an instrument he called la barque, which is used ...pour mesurer par l'art de Geometrie toutes distances tant longueurs, haulteurs que profondeurs (...to measure through the art of geometry all distances, be they lengths, heights, or depths) (Fig. 1).

The idea, then, was to create a direct, clear, and material link between abstract knowledge and the practical exercises that the military engineer or architect had to perform when developing technical projects.

Once the advantages of the use of this instrument were presented, Bachot focused on the topic of conic perspective through exercises applied to regular prisms, and he then provided his advertisement about the advantages of parallel perspective with respect to conic perspective, using as an example a sequence of drawings that began with a regular five-sided polygon, from which a three-dimensional image of a bulwarked fortress was quickly and easily constructed (Fig. 2). 
Fig. 1 The barque, an instrument used "to measure through the art of geometry all distances, be they lengths, heights, or depths" (Bachot 1587: not numbered (p. 16))

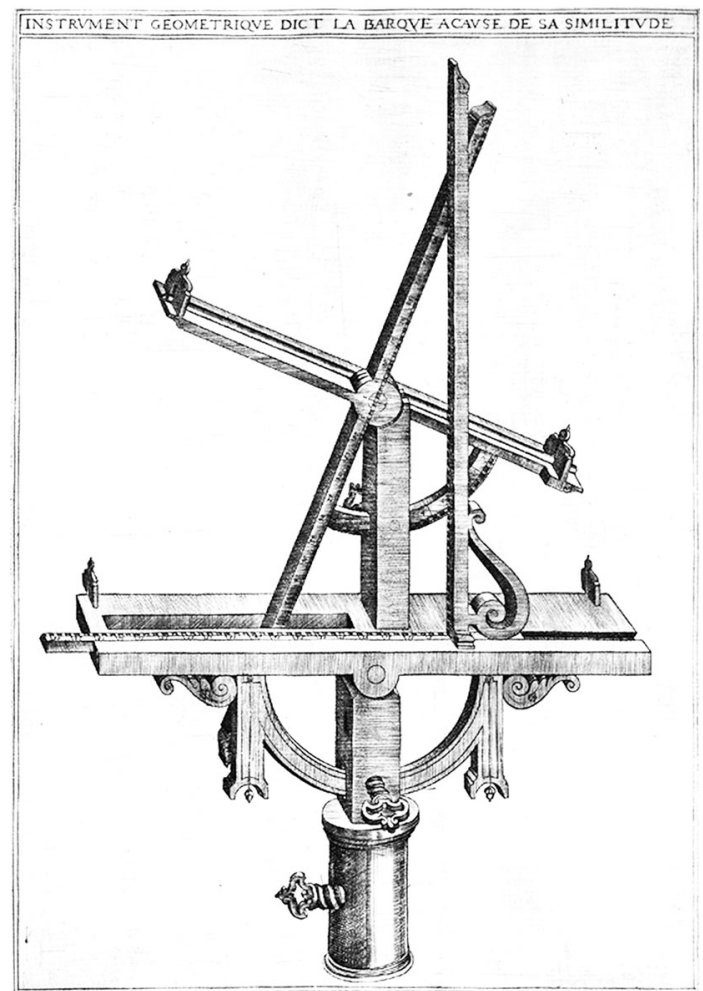

Following the tradition of other writers on fortresses, such as Zanchi (1560) and Cataneo (1584), Bachot adopted the bulwark as a central object of representation, increasing its scale and specifying its parts and dimensions. In this way, by allowing the reader to see the hidden lines and volumes that made up the initial lines, which was so important for the understanding of an engineer, it became clear that the drawing of the object was as important as the process of its graphic construction.

At the end of his book, Bachot presented a collection of bulwarked shapes with a consistent use of parallel perspectives and provided a graphic scale for the readers (Fig. 3).

These drawings - to which other military machines were added-were perhaps products of his experience: it is known that Bachot was personally close to the machine designer Agostino Ramelli, author of Le diverse et artificiose machine (1588) and most likely participated with him in military actions at La Rochelle and Turin, declaring himself a "captain" and later acting as fortress engineer for the first king of the House of Bourbon, Henri IV of France.

In Bachot's second book, published 12 years later and entitled Le gouvernail d'Ambroise Bachot ... (1598), he re-used a number of the illustrations contained in Le timon ... but in a different order, while also adding other illustrations related to 

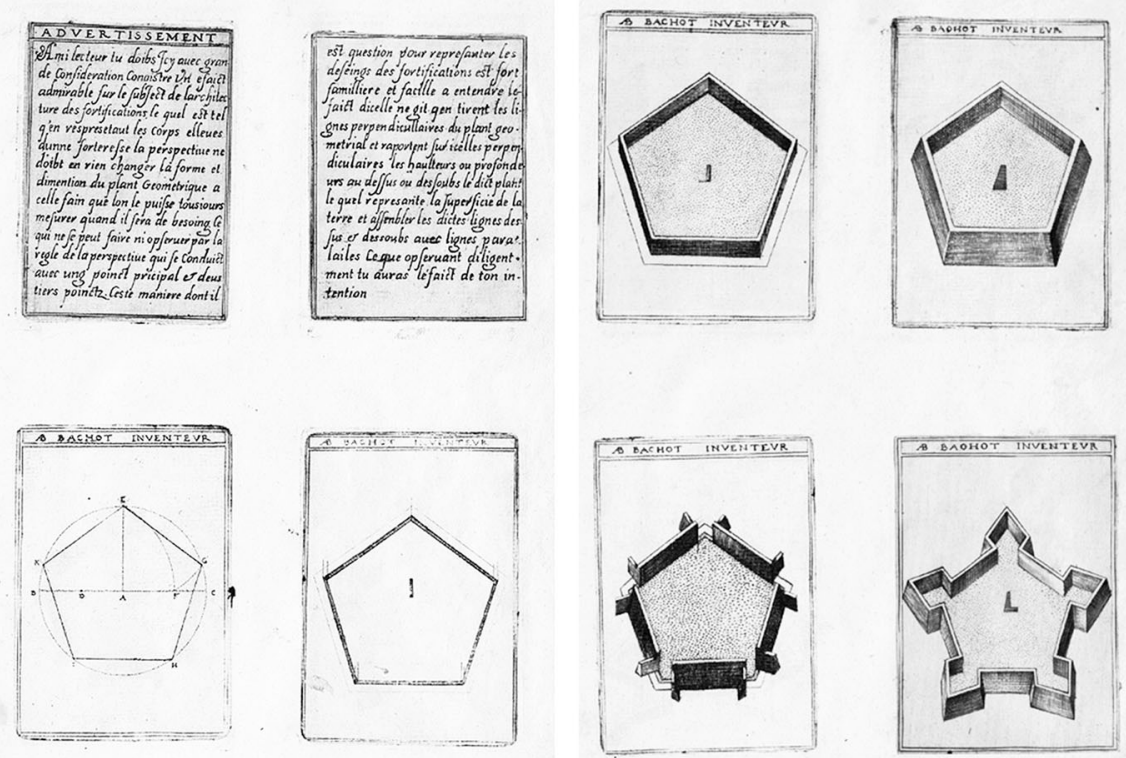

Fig. 2 Three-dimensional construction of a bulwarked building beginning with a plan drawing of a fivesided polygon using parallel perspective (Bachot 1587: not numbered (pp. 26 and 27))

fortified buildings and military machines. Once again, he defended parallel perspective, and this time he introduced the need to highlight shadows to make the preconceived ideas contained in the images more intelligible:

... j'ai commencé par géométrie, comme fondement et appui de notre perspective, par laquelle pourrez représenter l'idée de vos conceptions en l'art des fortifications et en après pour les corps élevés est de besoin de contenter l'oeil par les divers ombrages par lesquels l'oeil se contente de pouvoir discerner le but de ses intentions.

(I begin with geometry, as foundation and support of our perspective, through which we can represent the idea conceived in the art of fortifications to then, through raised bodies and with the aid of shadows, let the eyes understand the purpose of its intentions (Bachot 1598: 3), my trans.)

Bachot operated with the same didactic principles in this book as in Le timon ...; he assumed planar geometry as the starting point for his discussion and adopted the pentagon to develop his progressive changes until it acquired the shape of a bulwarked building. However, in Le gouvernail ..., the explanations are more extensive and precise, and Bachot uses dashed lines as teaching tools when explaining the procedures through which the heights of the bulwark are determined. In addition, he includes section drawings of the represented volumes. 


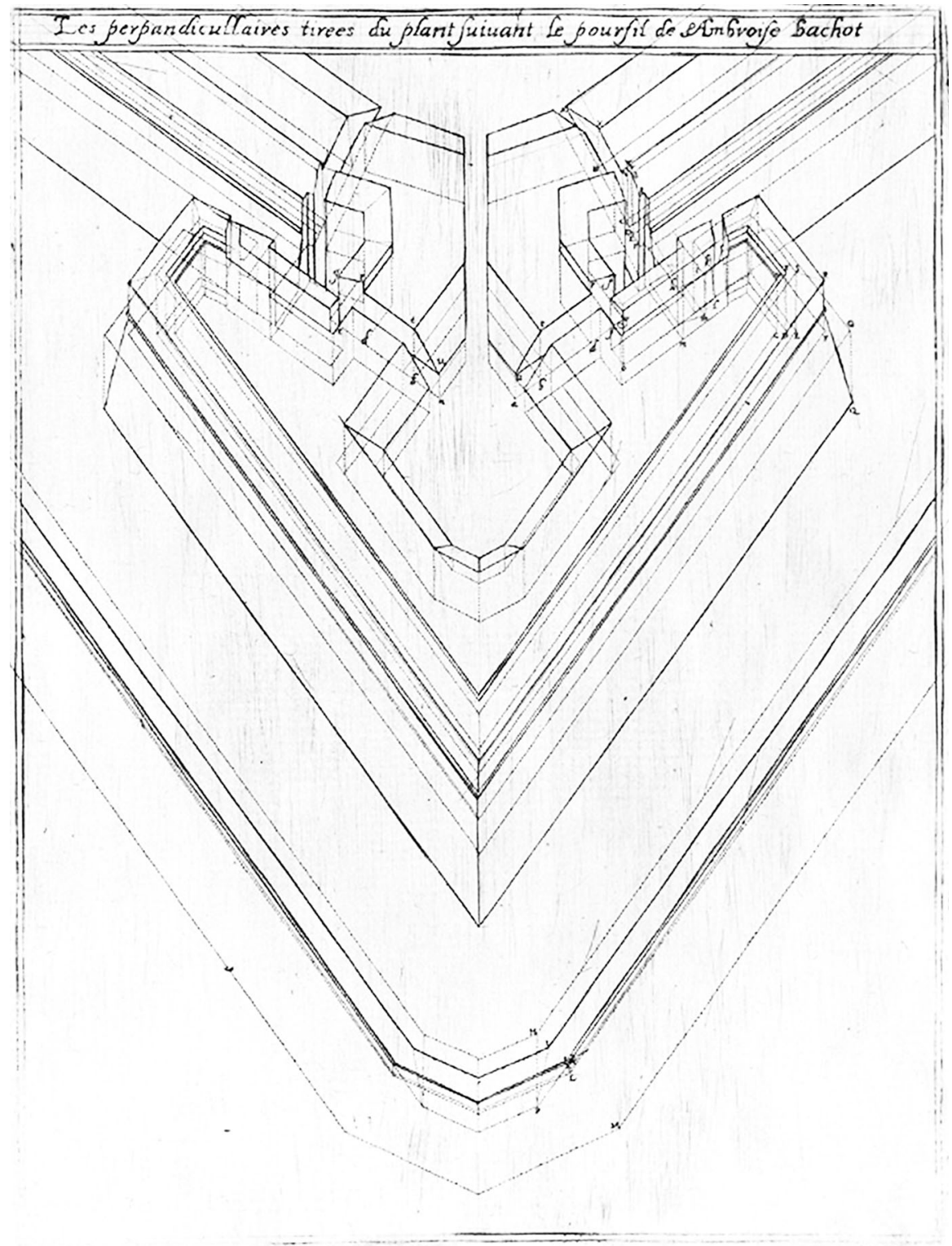

Fig. 3 Three-dimensional construction of a bulwark based on perpendicular lines drawn over the plan lines (Bachot 1587: not numbered (p. 33))

It is striking how operationally clear Bachot proved to be when differentiating between "conception" and "representation": it seems as though his discussion always focused on trying both phases equally, providing the necessary tools to make 


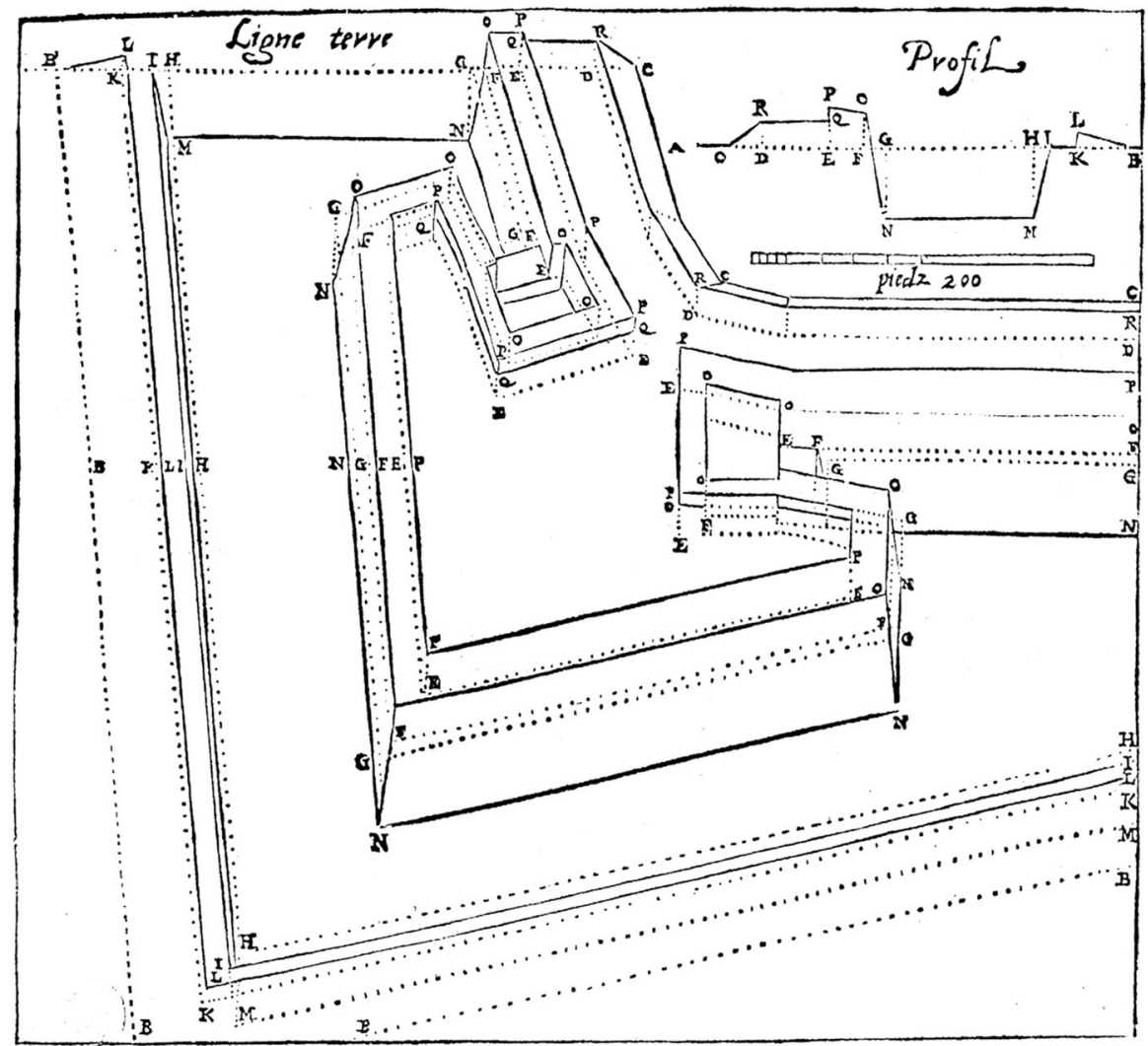

Fig. 4 Three-dimensional construction of a bulwark based on perpendicular lines drawn over the plan drawing (Bachot 1598: 23)

an idea not just visible for the designer but also suitable for a readership that demanded clarity and precision (Fig. 4).

\section{The Use and Dissemination of Military Perspective in France during the First Half of the 17th Century}

After the publication of A. Bachot's two books, parallel perspective acquired increasing popularity among French authors of treatises on fortification and received special attention from several of them.

At the dawn of the seventeenth century, a second edition of the book by Claude Flamand Le guide des fortifications et conduite militaire (1600) was published. The author used axonometric views as a didactic resource but did not incorporate them into the language of the military architect or engineer (Fig. 5). 
Fig. 5 Axonometric representation of a fortified enclosure (Flamand 1600: 208a)

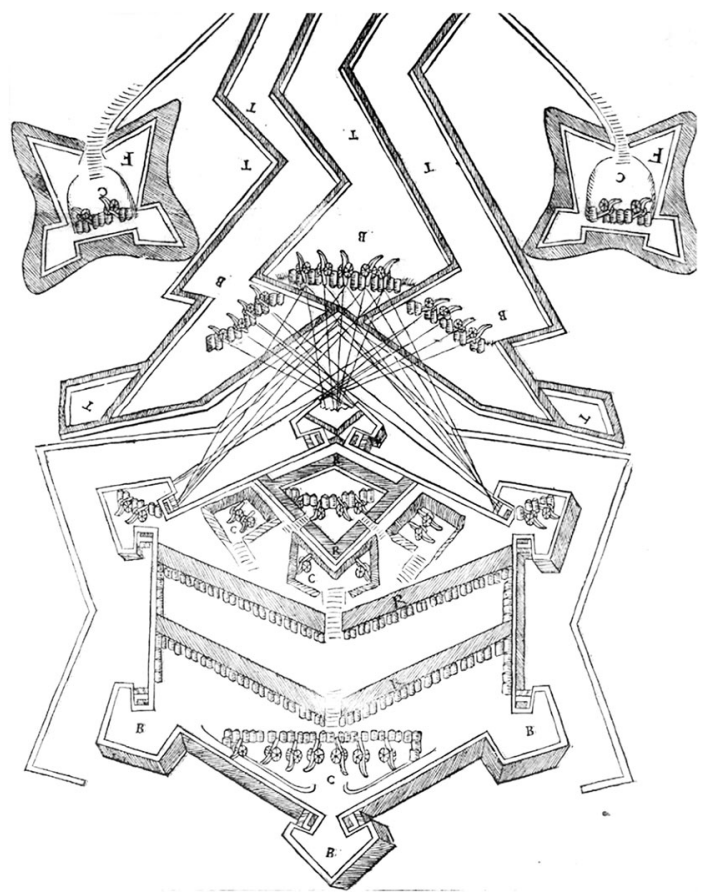

This strategy was characteristic of later works on Vauban's principles published by the Du Fay (1693) and Abbot Du Fay and Chevalier de Cambray (1703). In those later works, axonometric views were used to explain geometrical principles but were not used in representations of the complex defence systems that were designed by the famous French military engineer.

The early 17th century also witnessed the publication of an interesting work by Jacques Perret, Des fortifications et artifices d'architecture et de perspective (1601), in which the author made use of the parallel perspective to represent fortified city models; Perret portrays five urban plans of fortified towns in which he explores the great expressive capacities of military perspective, but he does not go into detail about his method.

In the years that followed, other works on parallel perspective were published, including Jean Errard's La fortification demonstree et reduicte en art (1620), Deville (1638) and Allain Manesson Mallet's Les travaux de Mars ou l'art de la guerre (1672). These all contained a variety of fortification images that relied on the parallel perspective. Some of the images are set in bucolic scenery that appears more suited to times of peace than war; however, the books contain no discourse that explain the use and value of the representations. 


\section{Military Perspective in Spanish Works on Fortresses in the 17th Century}

In the context of studies on Spanish fortifications of the 17th century, which were focused on learning from the French and Italian texts and translating, adapting, and imitating them, it wasn't until 1669 that a book was published that dedicated a few pages to the topic. The Epitome de la fortificación moderna (1669) by Alonso de Cepeda y Adrada comprised various treatises; Treatise VI focuses on "perspective and relief" and begins with a paragraph where the author openly proclaimed the uselessness of the conic perspective regarding the interests of soldiers and engineers:

Aunque esta parte de la Architectura militar es poco necessaria para el soldado, y de poca utilidad para el ingeniero. No obstante, porque muchas veces puede suceder, que el estudioso no tenga modo de levantar la planta de la plaza, por no poder acercarse a debida distancia, y que descubriéndola desde alguna eminencia desee el Príncipe verla, y quiera mostrársela el ingeniero en la forma, que se descubre desde aquella montaña.

(Even though this part of military architecture is of little necessity for the soldier, and of little use for the engineer, nevertheless, since many times the studious person has no way of surveying the courtyard plan due to the inability to get close enough, and since the prince may want to uncover it from some vantage point, the engineer may want to show him the shape and way in which it is observed from such a mountain (Cepeda y Adrada 1669: 209), my trans.)

In other words, for Cepeda y Adrada, the perspective was useful only in so far as it operated as a system of representation that allowed for communication between people, but not as a projection mechanism and much less as a technological tool.

To uncover a way of constructing a parallel perspective, he wrote (based on other authors who are not mentioned, except for the Jesuit Georges Fournier, author of Traité des fortifications (1649)):

Otros levantan perpendiculares sobre todos los ángulos de la plaza, de la longitud que se le da a la altura según el perfil que se hubiera tomado para tal designio; y conjuntándolas ordenadamente queda formada la figura, y con la apariencia de su altura, y de las demás partes que la constituyen.

Otros sin más circunstancias para dar elevación al cuerpo de la plaza, levantan perpendiculares sobre todos los ángulos de ella de la magnitud que debe tener su altura; y conjuntándolas ordenadamente consiguen el efecto, Pero en ambas á dos praxis siempre se reconocerá en estos cuerpos casi la misma apariencia; lo que no se deduce en el método que havemos deducido en la perspectiva; en donde se representa el cuerpo según la apariencia que tiene respecto del que le mira ...

(Others raise perpendiculars over all the angles of the courtyard, from the length given to the height according to the profile that would have been taken for such a design; and integrating them carefully yields the shape, with the appearance of its height, and that of the rest of the parts that make it up. 
Others with no other way of giving elevation to the body of the courtyard raise perpendiculars over all of its angles, of a magnitude equal to its height; and integrating them carefully yields the effect. But in both of them one will always recognise almost the same appearance in both bodies; what is not deduced in the method that we have deduced in the perspective; in which the body is represented according to the appearance it has from the perspective of whoever is looking at it ... (Cepeda y Adrada 1669: 217-218), my trans.)

Thus, Cepeda recognised different qualities in both representation systems: while conic perspective embodied the object according to the point of view of the observer, parallel perspective was limited to providing a three-dimensional appearance that did not always match reality but that became more useful for an engineer to "always measure the part that was desired" (Cepeda y Adrada 1669: 218, my trans.).

As in the work by Bachot, Cepeda dedicated several lines to defending the use of shadows in axonometries in providing greater depth to the vertical planes and facilitating their reading by untrained eyes "because the lines only represented the extremities of the surfaces of bodies, and to represent them completely, one required both clarity and shadows" (Cepeda y Adrada 1669: 220 my trans.) (Fig. 6).

The lessons that Cepeda y Adrada adapted from the French texts were applied in other Spanish treatises dedicated to military architecture both to represent fortified structures (in their entirety or fragments of them) as well as to constitute encyclopaedic texts. For example, in the treatise on artillery by Diego Ufano y Velasco (1613), the author used the parallel perspective to represent war scenes. Sebastián Fernández de Medrano, in his treatise, El Perfecto Artificial, Bombardero $y$ Artillero (1699) used it to represent scenes of the constructive labour of curtain walls and bulwarks. In the case of encyclopaedic books with pedagogical intent, we can highlight the work attributed to Josep Chafrión, the Marqués de Leganés, Escuela de Palas ... (1693), chapter 10 of which is dedicated to scenography or perspective, including careful illustrations that showcase the author's mastery of cavalier perspective, which he called by its name, even though he did not provide details on how to create it (Fig. 7).

In the Compendio mathemático by Tomás Vicente Tosca (1727), also of an encyclopaedic nature, the author extolled parallel perspective:

... que sin guardar el rigor de las leyes ópticas, es muy proporcionada para las Fortificaciones, por lo que se llama Perspectiva Caballera Militar, y también Paralela, por formarse de solas líneas paralelas; con esta se conservan en la descripción las propias dimensiones Geométricas de todas las partes de una Fortificación, lo que no es posible con la otra, por averse de disminuir según sus reglas, las partes más remotas aunque sean iguales a las más cercanas.

(... which, without maintaining the rigor of optical laws, is very well proportioned for Fortifications, which is why it is called Military Cavalier Perspective, and also Parallel, since it is formed by single parallel lines; with it, one can maintain the Geometric dimensions of all the parts of a Fortification, which is not possible with the other perspective, because 
Fig. 6 Representation of volumes through parallel perspectives (Cepeda y Adrada 1669: Estampa 30)

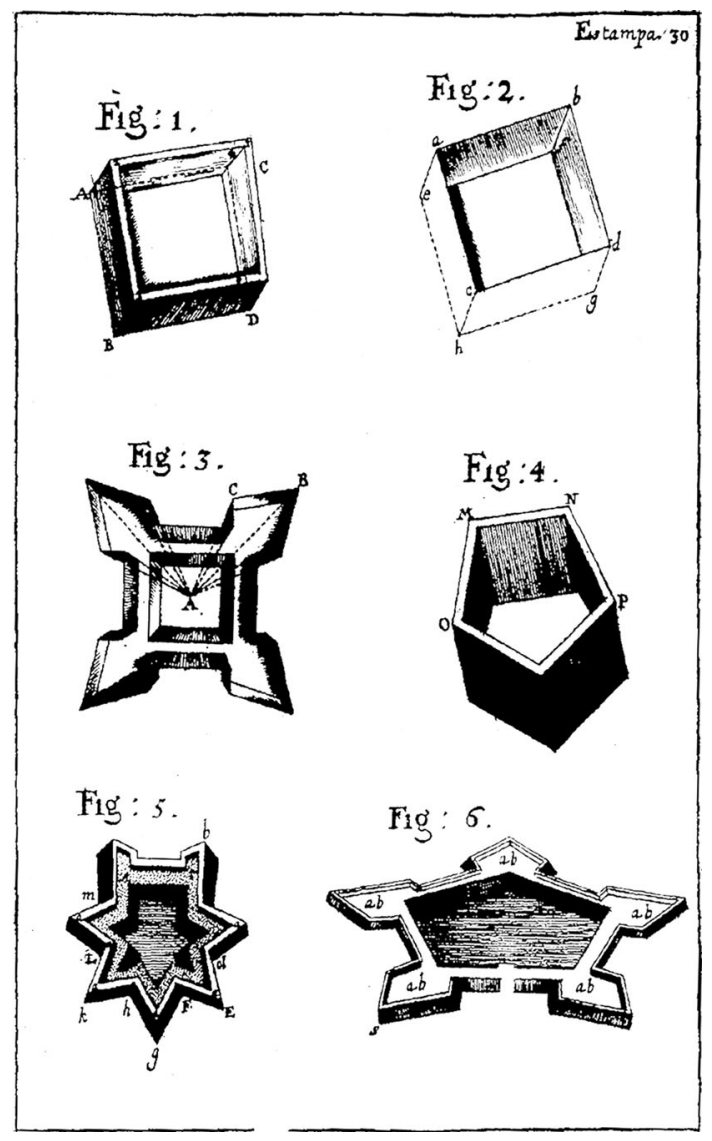

according to its rules, the more remote sections are reduced, even when they are the same size as those that are closer (1727: 319), my trans.)

We must note that, at least in Spain, the different forms of perspective (conic and parallel) were taught in engineering schools, as documented in the case of the Real Academia de Matemáticas de Barcelona, which operated in that city during most of the eighteenth century, and where many of the new professionals learned to draft their projects both on the peninsula and in overseas colonies (Galindo 2008).

\section{The Works of Jean Du Breuil}

In 1674 a book appeared in Paris signed by le Sieur de Bitainvieu entitled L'art universal des fortifications ... (Du Breuil 1674) that explained in great detail how to use military perspective to represent the different parts of a fortified building. The name Bitainvieu was actually an anagram used by the Jesuit priest Jean Du Breuil, who was a little-known character of contemporary historiography (Michaud 1885) and author of the three-volume La perspective pratique (1642-1648). A second 
Fig. 7 Cavalier projection of a complete system of fortifications (de Leganés 1693: Bk. I, 147)

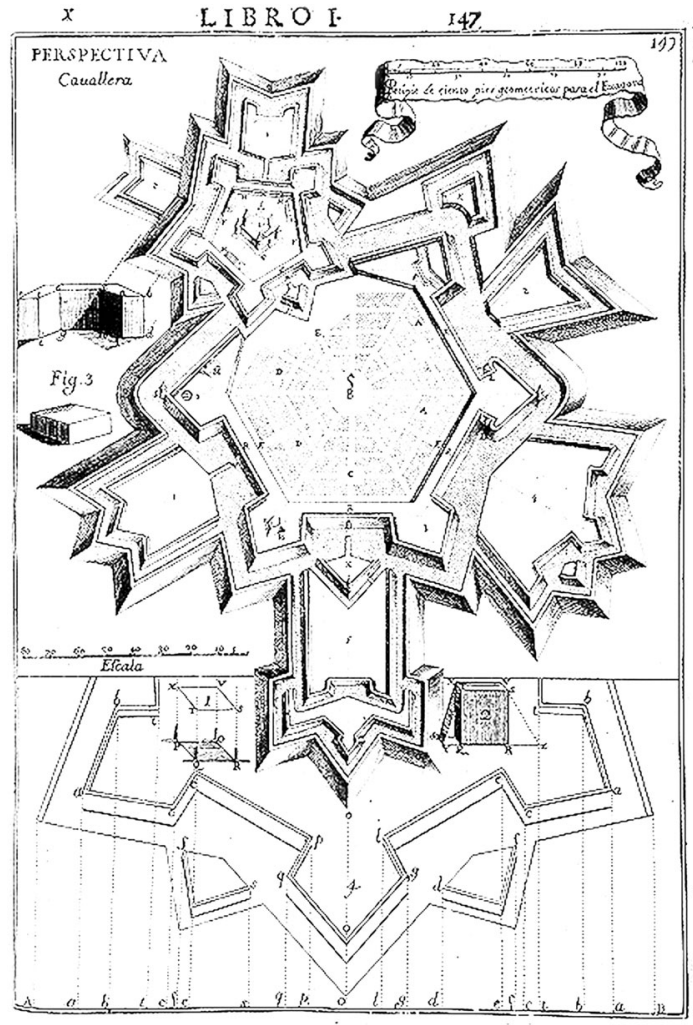

edition was published in 1651 and reprinted in 1663, and English translations were eventually published as well (Du Breuil 1642; Harrison and Wood 2000).

However, Du Breuil did not refer to parallel perspective in La perspective pratique, even when discussing the tri-dimensional representation of fortified buildings. After considering a brief "theory of perspective" through a set of basic definitions and principles, the author explained how different types of plans were represented using one or more vanishing points; once that topic was concluded, he proceeded to the basic rules for elevations and how to "place fortifications into perspective", to which he dedicated only one page and one illustration, stating that:

We need not here repeat the Method of diminishing, or putting in Perspective, the Plans of all Sorts of Fortifications ... To raise them there is no more Difficult than in a bare Wall; only more Time is required, by Reason of the greater Number of Angles that are to be drawn all to the Line of Elevation ... (Du Breuil 1749: 114).

It appears that for Du Breuil, the perspective of a fortification was an unimportant subject, a source of annoyance, and a waste of time, given the number of corners in bulwarked figures. He perhaps also recognised its lack of usefulness for the objectives of a military engineer. 
In contrast, in his L'art universal des fortifications (1674), Du Breuil concentrated his efforts on explaining how the French, Dutch, Spanish, and Italians developed different fortification systems based on the magnitudes of the lines and the arrangements of complimentary works. The text is divided into four treatises. The first contains definitions, names, terms, figures of courtyards, and different types of constructions. The second treatise describes the methods of fortifying by nationality. The third explains the methods of fortifying regular and irregular courtyards. The fourth treatise explains la Methode pou élever les Plans des Fortifications, \& les faire paroistre sur le papier, comme ells sont en effet sur la terre (the method for raising the plans of fortifications, both on paper and on the ground) and aims at describing la vraye perspective militaire (the true military perspective), as expressed in the frontispiece of the book (Fig. 8).

In the fourth treatise, Du Breuil clearly favours raising heights over the plans, in as much as this method facilitated the understanding of the drawings for anyone who was not trained in reading two-dimensional renderings of three-dimensional objects. In addition, according to the author, perspective "corrupted all the plans", that is, distorted them in such a way that.

... \& que ceux qui ne sçavoient pas, ni les secretes de cette science, ni ses effets, croient qu'ne figure quarrée fuft un Trapeze; \& un Polygone bien reguliere leur paroissoit une Place toute irreguliere, oú tous les Bastions sont estropiez \& sans defenses; ceux du fond trop petits, au respect de ceux du devant; en un mot, que plus de la moitié du monde n'y connoissoit rien.

(... and those who do not know the secrets of this science, or its effects, believe that a square figure seems like trapezium; and a regular polygon appears to them as an irregular place, where all the bastions are smooth and without defenses; those in the rear seem to them very small with relation to the ones in front; in a word, more than half the world knows nothing (De Breuil 1674: 219), my trans.)

Such a harsh evaluation of conic perspective allowed Du Breuil to present military perspective to the reader, now with its own name, through a series of nine practical exercises under the title La perspective militaire, pour faire voir les fortifications elevées, sans changement du plan geometral (military perspective, to show fortifications raised without changing the geometrical plan).

The first exercise adopts the square as the basic form from which all of the exercises are developed, gradually increasing the degree of complexity and integrating the drawing with shadows to make the drawings easier to understand (Fig. 9).

Specifically dedicated to fortifications, the author explains how to render the slopes of walls and the depths of moats through military perspective, and how to integrate bulwarks and other exterior defensive structures in the regular polygons. At the end of this discussion, he highlights the method's qualities, including easy, rapid execution and a lack of deformity of the geometric plan, and he extends the method to other types of buildings (Fig. 10). 


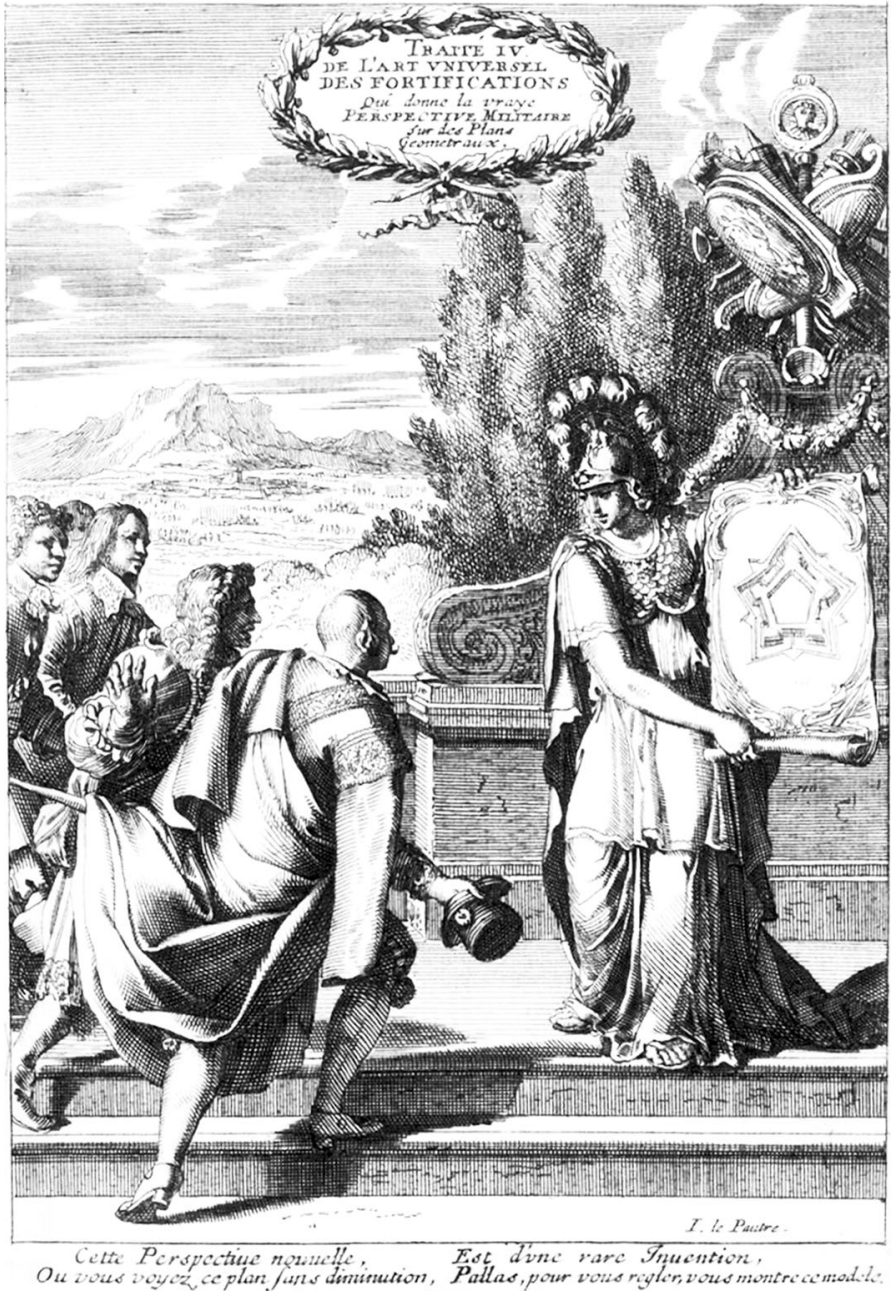

Fig. 8 The frontispiece of Du Breuil's Treatise IV: "On the universal art of fortifications which gives the true Military Perspective on geometrical plans", with Palas displaying the plan of a fortification. The caption below the image reads: "This new perspective is a rare invention that allows for examination of the plan without reduction (Du Breuil 1674)

The influence of Du Breuil's work is evident in books that followed, such as Blaise François Pagan's Les fortifications du Comte de Pagan (1689), in which the author affirms the existence of an engineer's particular way of representation:

Il y a une autre maniere de representer une Forteresse qui est fort en usage chez les Ingenieurs, qui est de la dessiner de telle sorte que l'on en découvre tout d'un coup la Plan \& les élevations, ce qui est une espece de PERSPECTIVE, dans laquelle on suppose qu'une Forteresse foit vüe d'une distance infinite, en sorte que la ligne visuelle fasse avec le Rez-de-chaussée un Angle de 453 degrez. 
Fig. 9 Graphic construction of the slopes of a wall with a square plan using military perspective (Du Breuil 1674: 229)

Fig. 10 Representation of bastions using military perspectives (Pagan 1689: Ch. I, 48)
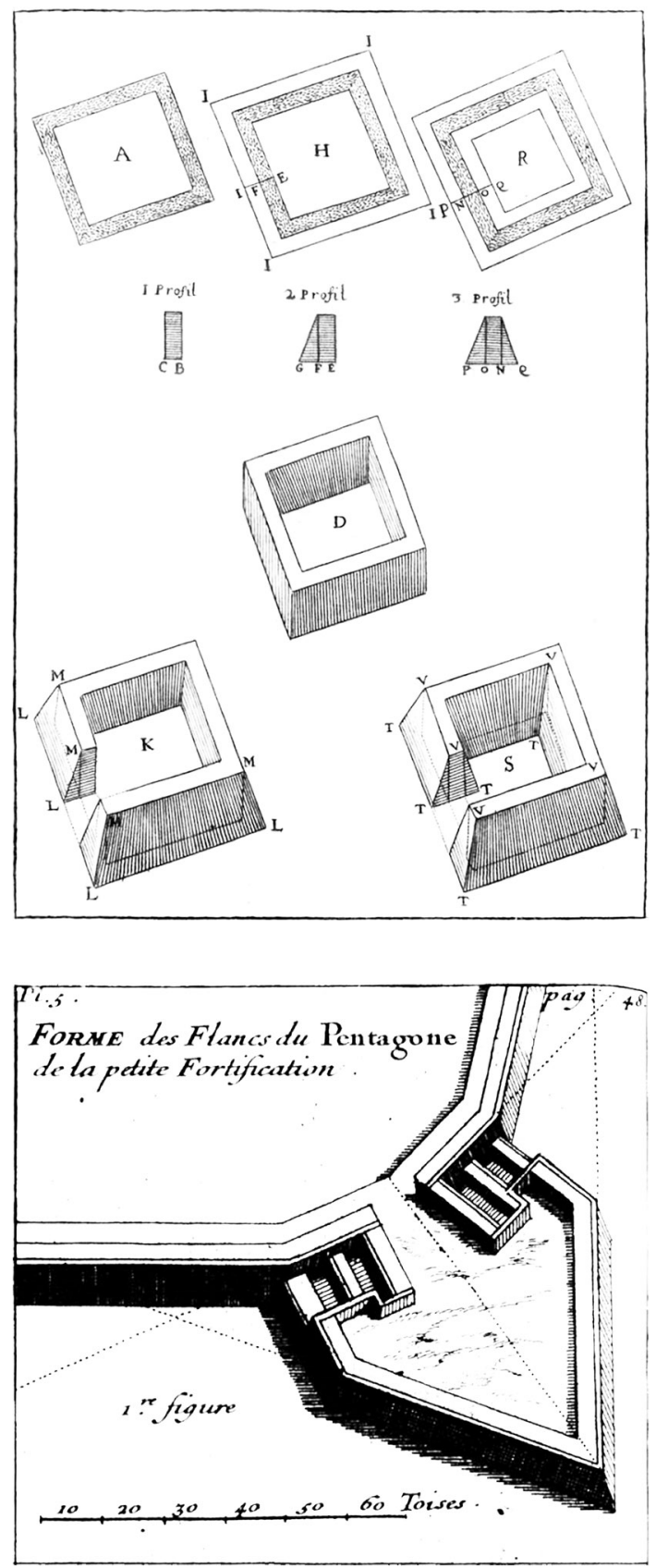

(Another way exists to represent a fortress; it is often used by engineers and consists in drawing it in a way that it shows simultaneously the plant and the elevations, which is a sort of PERSPECTIVE that assumes that a fortress is 
seen from an infinite distance so that the visual line makes with the lower plant a $453^{\circ}$ angle (1689: 32), my trans.)

Pagan makes use of military axonometric views to explain the shapes of bastioned flanks in fortifications of different sizes. From that point on, axonometric views would be here to stay.

\section{Conclusions}

Parallel perspective was clearly defined by the end of the seventeenth century-at least through the treatises on military architecture printed in France and Spain-as part of engineers' graphic tools that allowed them to represent an entire fortified building or its parts easily and quickly in a three-dimensional figure. However, the use of parallel perspective does not appear to be linked to processes of invention or conception; rather, it was referred to by the authors who considered it as a tool for efficient communication, not only because of its production but also because it avoided the deformation of plans and lines.

There is no written evidence-at least until the beginning of the eighteenth century-of the use of parallel perspective within the technical-constructive practice involving the quantifying of volumes for construction, even though in some cases it was linked to the sequential description of operational processes or the representation of actions.

Translated from the Spanish by American Journal Experts.

\section{References}

\section{Primary References}

Androuet du Cerceau, Jacques. 1582. Livre III d'architecture. Paris: J. A. du Cerceau. Androuet du Cerceau, Jacques. 1576. Leçons de perspective positive. Paris: Mamert Patisson.

Androuet du Cerceau, Jacques. 1576b. Le premier volume des plus excellents bastiments de France, Paris, s.n.

Androuet du Cerceau, Jacques. 1583. Petit traitte des cinq ordres de colomnes, Paris, s.n.

Bachot, Ambroise. 1587. Le timon du capitain Ambroise Bachot... Paris: A. Bachot.

Bachot, Ambroise. 1598. Le gouvernail d'Ambroise Bachot ... lequel conduira le curieux de géométrie en perspective dedans l'architecture des fortifications, machine de guerre et plusieurs autres particularitez y continues. Melun: chez l'auteur.

Cataneo, Girolamo. 1584. Dell Arte Militare, libri cinque .... Brescia: Pietro Maria Marchetti.

Cepeda y Adrada, Alonso de. 1669. Epitome de la fortificación moderna ...: y otros diversos tratados de la perspectiva, geometria practica, y del modo de sitiar, y defender las plazas, y de la construccion de las baterias y minas, y artificios de fuego.... Brussels: Francisco Foppens.

Deville, Antoine. 1638. Les fortifications de chevalier. Lyon: Jean Barlet.

Du Breuil, Jean. 1642. La perspective pratique, 3 vols. Paris: M. Tavernier/F. Langlois.

Du Breuil, Jean (Silvère de Bitainvieu). 1674. L'art universal des fortifications françoises, holandoises, espagnoles, italiennes ... Paris: chez Jacques Du Breuil.

Du Breuil, Jean, Ephraim Chambers, and James Hodgson. 1749. The practice of perspective, or, An easy method of representing natural objects according to the rules of art... London: Tho. Bowles and John Bowles. 
Du Fay, Abbot. 1693. Manière de fortifier selon le method de monsieur de Vauban, avec un traité preliminaire des principes de geométrie. Paris: Jean Baptiste Coignard.

Du Fay, Abbot, and Chevalier de Cambray. 1703. Véritable manière de bien fortifier de Mr. de Vauban. Amsterdam: Pierre Mortier.

Errard, Jean. 1620. La fortification demonstree et reduicte en art. Paris: s.n.

Flamand, Claude. 1600. Le guide des fortifications et conduite militaire. Montbeliard: Jacques Foillet.

Fournier, Georges. 1649. Traité des fortifications ou architecture militaire : tiré des places les plus estimées de ce temps, pour leurs fortifications. Paris: Jean Hénault.

Leganés, Marqués de. 1693. Escuela de Palas ò sea curso mathematico. Milan: Pandulpho Malatesta. Maggi and Castriotto. 1564. Della fortificatione della cittá. Venice: Rutilio Borgominiero.

Manesson Mallet, Allain. 1672. Les travaux de Mars ou l'art de la guerre. Paris: Frederic Leonard.

de Medrano, Sebastián Fernández. 1699. El perfecto artificial, bombardero y artillero. Brussels: Lamberto Marchant.

Pagan, Blaise François. 1689. Les fortifications du Comte de Pagan. Paris: chez Nicolas Langlois.

Perret, Jacques. 1601. Des fortifications et artífices d'architecture et de perspective. Paris : s.n.

Ramelli, Agostino. 1588. Le diverse et artificiose machine. Paris: chez l'auteur.

Tosca, Tomás Vicente. 1727. Compendio mathemático: en que se contienen todas las materias más principales de las ciencias .... Madrid: Antonio Marín.

Ufano y Velasco, Diego. 1613. Tratado dela Artilleria y uso della Platicado por el Capitan Diego Ufano en la Guerras de Flandes. Brusselas: Ivan Momarte.

Zanchi, Giovanni. 1560. Del modo di fortificar le cittá... Venice: s.n.

\section{Secondary References}

Camerota, Filippo. 2008. The eye of the Sun. In Carpo, Mario \& Lemerle, Frédérique (Eds.). Perspective, projections \& design. New York: Routledge: 115-125.

Deforge, Yves. 1981. Le graphisme technique. Son histoire et son enseignement. Neuilly-sur-Seine: Centre de recherche sur la culture technique.

D’OrgeIX, Émilie. 2008. "Fortification et perspective militaire au XVIIe siècle en France". In CARPO, Mario and Lemerle, Frédérique (Eds.). Perspective, projections \& design. New York: Routledge: 127-140.

GALINDO, Jorge. 2008. The teaching of perspective as a part of fortifications in the $18^{\text {th }}$ century: the case of the Barcelona Royal Academy of Mathematics. Varia Historia 24(40): 465-481.

Harrison, Charles, and Peter Wood. 2000. Art in theory, 1648-1815: an anthology of changing ideas. Oxford: Blackwell Publishers Ltd.

Michaud, Joseph. 1885. Biographie universelle ancienne et modern. Paris: Chez Madamme C. Desplaces.

VÉRIN, Héléne. 2006. Les paradoxes de la perspective dans la littérature technique. In CojANNOT-LEBlanc, Marianne; Dalai, Marisa \& Dubourg, Pascal (Eds.). L'artiste et l'œuvre àl'épreuve de la perspective. Roma: École française de Rome: 243-270.

Jorge Galindo Díaz is a Doctor of Architecture and Senior Lecturer in the School of Architecture and Urbanism at the National University of Colombia, Manizales. 